\title{
Distributive justice: A common good for altruistic organ donation
}

\author{
Osebor Ikechukwu Monday ${ }^{{ }^{*}}$, Paul Ikechukwu Ogugua ${ }^{2}$ \\ Lecturer ${ }^{1 *}$, Department of Arts and Humanities, Delta State Polytechnic, Ogwashi-uku, Nigeria. \\ Senior Lecturer ${ }^{2}$, Department of Philosophy, Nnamdi Azikiwe University, Awka, Nigeria
}

Editor, Human organs are therapies for patients suffering from organ failure. This medical breakthrough is challenged with non-availability of organs because of the ineffective distribution of donated organs. Although organ distribution is a complex process, the privileged class engineered organ marketing has led to the organ crisis. The organ crisis occurs when the demand for organs is far greater than the supply. ${ }^{1}$

Organ marketing is an unethical procurement and disbursement of organs or tissues, for financial gains. $^{2}$ Organ marketing is neo-cannibalism and is the distribution and procurement of organs based on the worth of the individuals (financial or statusbased).

Torsten Trey et al argue that neo-cannibalism is an inverse form of organ donation. It involves the manipulation of the organ distribution system and the politicization of organ donation. Neocannibalism omits patients that are supposed to receive an organ based on the regular waiting times. Hence, this approach possibly jeopardizes the lives of candidates on the organ waiting list. $^{3}$ Torsten Trey et al cite the World Health Organization (WHO) that the desperate attempt to accelerate the allocation of an organ, by omitting the ethically established pathway of public organ distribution system worsens the organ shortages. ${ }^{3}$

John Rawls would say that "the common good" refer to the total of social conditions that answer to the interest of equal citizenship. In this sense,

\footnotetext{
*Correspondence: Osebor Ikechukwu Monday E mail: osebordarry@yahoo.com

https://orcid.org/0000-0002-2642-662X Received: 08/06/2020

Accepted: 24/06/2020

DOI: http:/doi.org/10.4038/slja.v28i2.8609
}

candidates on the waiting list should be treated based on the principle of justice. ${ }^{4}$ The Centre for Bioethics presents the unethical criterion of the organ distribution thus;

(a) the argument that individual worth does not determine medical need (b) the dilemma to make decisions on who is worthy or not worthy to receive an organ (c) the slippery slope of determining an individual's worth and whether or not it is fair to label someone worthy of a medical procedure. ${ }^{5}$

Individual worth is a racial expression in the organ donation system. Individual worth repudiates human dignity and treats the human being as a means to an end. The Centre for Bioethics affirms equal-access of the donated organs among patients on the waiting list. ${ }^{5}$

However, there are many methods of organ distribution, such as organ marketing, individual worth, and neo-cannibalism. Distributive justice seems the most acceptable criteria for organ allocation. Let us discuss distributive justice as a practical approach for organ distribution.

\section{Distributive justice for common good}

Distributive justice is a liberal philosophy, which seeks to specify and not to segregate the distribution of organs. Puja Mondal cites Aristotle that distributive justice is the most powerful law to prevent revolution. ${ }^{6}$. Distributive justice advocates proper and proportionate allocation of offices, honours, goods and services among the citizens for the common good of the society. The centre for bioethics reports that distributive organ donation is not one "right" way to distribute organs, but rather many ways a person could justify giving an organ to patients suffering from organ failure. ${ }^{5} \mathrm{We}$ contend that unjustified approaches such as individual worth and organ commerce be jettisoned for the common good. 
The philosophy of distributive justice affirmed equity and fairness. Distributive method distributes burdens and benefits among humanity. Distributive justice is judgmental because when decisions are reachedpeople tend to evaluate the outcome as fair or unfair.

"Equality" or "social" justice is the equitable sharing in the allocation of organs. ${ }^{7}$ Distributive justice addresses constraints that confront opportunities among the citizens. Justice advanced the maximization of the least advantaged position. The question is, is distributive justice legalism? Distributive justice may not be legalism or formal theory of decision-making rather, it provides guidelines to make a justified moral decision. ${ }^{8}$ The transplant surgeons and other health workers should work together for the common good of patients on the organ waiting list. Centre for bioethics cites the University of Washington School of Medicine that organs can be distributed based on the following criteria

1. To each person an equal share

2. To each person according to need

3. To each person according to the effort

4. To each person according to the contribution

5. To each person according to merit

6 . To each person according to free market exchanges. ${ }^{5}$

Additionally, the National Organ Procurement Organization (NPO), establishes a uniform organ procurement and distribution system. Thus;

The first criterion is the geographic area of the donor and the recipients. Local organs first allocated to local recipients. If there are no suitable local recipients, organs distributed to the recipients in the state or the region and finally, offered to the entire nation. The second criterion is the blood group compatibility/ matching. The third criteria are (a) the time of waiting, (b) immunological matching, (c) medical urgency, (d) the age of the patient, where pediatric patients less than 11 years of age are given higher points. ${ }^{9}$

We may not refute the above medical criterion for organ allocation. We argue that distributive justice would checkmate unhealthy criteria of organ distribution. However, the implementation of the distribution of justice is challenged by private morality. Distributive justice for organ allocation does not mean treating all patients the same, but it requires giving equal respect, access and concern to each patient on the organ waiting list.

Ironically, the allocation of organs based on individual worthiness such as religion, race, ethnicity socio statue or economic class and gender would negate the distributive justice. Although there may be special cases such as the organ matching, skin-tone, face and hand transplant call for an exception in the allocation of vascularized composite allografts (VCAs). ${ }^{8}$ In the above case, we contend that it would negate the principle of distributive justice.

Distributive justice is criticized as a top-down approach, which does not allowance the individual cases and stories. Critics contend that simply applying the principle of distributive justice would slow down in making ethical decisions and would lead to a linear way of doing ethics - that is, relationship-based approaches are not considered adequately. ${ }^{10 .}$ To correct the above misconceptions, it is important to acknowledge that there has never been, and never will be, a purely libertarian society or Rawlsian society or any society whose distribution conforms to one of the proposed by above theory. Distributive justice is a useful thought that provides moral guidance for patients suffering from organ failure.

\section{Concluding reflections}

Direct altruistic organ donation would discourage the equitable distribution of organs. Distributive justice is a policy-based method of organ distribution. It provides equal consideration for patients, for the efficient use of donated organs. It would help to reduce potential waste of organs by minimizing cold ischaemic time. Social justice is a moral ground for the citizens, to participate in organ donation initiatives. Additionally, it helps to decrease the cost of organ procurement. The ineffectiveness system in organ allocation discourages potential donors. However, the obstacles that confront the implementation of distributive justice are not enough to throw away the theory. We argue that organs be allocated based on the principle of justice, equity and fair play, for the common good of the society. 


\section{References}

1. Osebor I. Is Organ Farming a Panacea to Organ Crisis? Ethical Implications. Journal of Asian and International Bioethics. 2018; 28 (5) p.104-108

2. Nancy Scheper-Hughes Neo-Cannibalism and ISIS: Organs and Tissue Trafficking During Times of Political Conflict and War. Research gate 2017. Available at https://www.researchgate.net/publication/3144055 63 NeoCannibalism and ISIS_Organs and Tissu e Trafficking_During_Times_of Political_Conflic $\mathrm{t}$ and War/link/599703e8458515df2a258423/dow nload

3. Trey T, Caplan AL, Lavee J. Transplant ethics under scrutiny - responsibilities of all medical professionals. Croat Med J. 2013 ;54(1): 71-74. https://doi.org/10.3325/cmj.2013.54.71

PMid:23444249 PMCid:PMC3583396

4. Aldcroft A. Measuring the Four Principles of Beauchamp and Childress. BMC Series blog. 2012;1-3. Available at https://blogs.biomedcentral.com/bmcseriesblog/20 12/07/13/measuring-the-four-principles-ofbeauchamp-and-childress/

5. Ethics of Organ Transplantation. Center for Bioethics February 2004. Available at https://www.ahc.umn.edu/img/assets/26104/Organ Transplantation.pdf

6. An end-in-itself. Available at http://www.bbc.co.uk/ethics/introduction/endinitsel f.shtml

7. McKee AF. What Is "Distributive" Justice? Journal Review of Social Economy Pages 1-17 | Published online: 04 Jan 2007. https://doi.org/10.1080/758528118

8. Ethical Principles in the Allocation of Human Organs. 2015 The Ethics Committee in 1992 and revised in 2010, updated 2015. Available at https://optn.transplant.hrsa.gov/resources/ethics/eth ical-principles-in-the-allocation-of-human-organs/

9. Abouna GM. Ethical Issues in Organ Transplantation. Journal of medical principles and practice, 2003;12:54-69

https://doi.org/10.1159/000068158

PMid:12566971

10. Karen L. Rich Introduction to Bioethics and Ethical Decision Making. Available at http://samples.jbpub.com/9781284059502/Chapter 2_Sample.pdf Stanford Encyclopedia of Philosophy. 